\title{
The Effect of Using Simple Aircraft Concrete Media on the Mastery of Concepts in Inquiry Science Learning in Elementary School Students
}

Erni Asmawati

SDN 1 Nagrikidul, Purwakarta city, West Java, Indonesia

Email:erni.asmawati81@gmail.com

Muhamad Taufik Bintang Kejora

Faculty of Islamic Studies, Universitas Singaperbangsa Karawang,

Karawang city, West Java, Indonesia

Email:muhamad.taufik@fai.unsika.ac.id

\begin{abstract}
This study aims to determine the increase in mastery of concepts in inquiry learning science through simple concrete media. This research is expected to help teachers solve the problems of learning science at the elementary school level. The research approach used quantitative research with a quasiexperimental method and a nonequivalent control group design. The study involved 60 fifth grade students of SDN 1 Nagrikidul, Purwakarta district. In the control class, conventional learning assisted by audio-visual media is applied. And the experimental class applied science learning by inquiry using concrete media. The results showed that the gain normalization test for increasing the mastery of science concepts in the experimental class $(\mathrm{N}$-gain $0.44)$ was greater than the control class's gain value ( $\mathrm{N}$-gain 0.23). Based on the test results, the difference between the two means is obtained count $=3.368>$ $t_{\text {table }}=2.045$, with a sig. $0.002<\alpha$ amounting to 0.05 , then $\mathrm{HO}$ is rejected, and $\mathrm{Ha}$ is accepted. Therefore Inquiry science learning by utilizing concrete media can significantly improve the mastery of science concepts in elementary school students.
\end{abstract}

Keywords: Concrete Media, Inquiry, and Mastery of Science concepts. 


\section{INTRODUCTION}

Natural science is learning for elementary school students who play an important role in training critical power, analysis, and higher-order thinking about natural phenomena or events. Also, science plays an essential role in developing science and technology through experiments and discoveries (Shahali, Halim, \& Treagust, 2015).

In essence, science can be viewed in terms of products, processes, and scientific attitude development (Muakhirin, 2014: 53). In both conceptual and practical settings, science studies nature and everything in both living and nonliving. Science learning broadly includes natural phenomena arranged systematically through various experiments and observations by Samatowa, meaning that science has interrelated dimensions of products, processes, and attitudes (Samatowa, 2010: 3). Product dimensions in science are facts, concepts, principles, laws, and theory. Science as a product can be interpreted as the result of a process, in the form of knowledge taught both inside and outside of school (system of ideas). Scientific process activities that produce products in the form of experience will not be successful without the actors or researchers (Suduc, Bizoi, \& Gorghiu, 2015).

Science as a process can be defined as a scientific activity that discusses natural phenomena and finds new knowledge (ways of finding out). Thus the process dimension is the process of obtaining natural science compiled and obtained through scientific methods. Furthermore, it is said that science is not only a collection of knowledge about objects or living things but is a way of working, a form of thinking, and a way of solving problems (Setiawan, Suhartono, \& Triyanto, 2019: 180). 
In the implementation of science learning, both the process and the findings are interconnected. The discovery process is needed to gain mastery of concepts. The results are in the form of an understanding of science, which emphasizes direct giving to develop student competencies in understanding science (Rosarina, Sudin, \& Sujana, 2016: 372). In understanding science, a learning process is needed that trains students to know how a phenomenon can occur and understand and have to be able to explain why this phenomenon can occur (Duruk, Akgün, Doğan, \& Gülsuyu, 2018).

Mastery of science learning concepts needs to be developed to find their concepts to understand the material and improve their learning outcomes. This becomes very important for students as a provision in studying phenomena in nature in specific ways to obtain this knowledge and be useful in developing that knowledge in the future (Rosarina et al., 2016). Mastery of concepts is closely related to the cognitive realm. This cognitive domain includes the ability to restate the concepts or principles that have been learned concerning thinking skills, competence in gaining knowledge, recognition, understanding, conceptualization, determination, and reasoning. Learning objectives in the cognitive realm (intellectual) or what according to Bloom (1959) are all activities involving the brain divided into 6 levels according to the lowest to the highest level which is denoted by $\mathrm{C}$ (Cognitive) including $\mathrm{C} 1$ (Knowledge), C2 (Understanding / Comprehension), C3 (Application / Application), C4 (Analysis / Analysis), C5 (Synthesis / Synthesis), and C6 (Evaluation / Evaluation) (Handika \& Wangid, 2013: 87)

Furthermore, it emphasized that to solve problems, a student must know the relevant rules, and these rules are based on the concepts they get. The aspects of mastery of the science concept can be achieved optimally by 
students. Of course, the right media, models, strategies, methods, and approaches are needed to provide cognitive abilities (Ardianto \& Rubini, 2016: 33). In general, science learning in elementary schools has not led to efforts to direct students in mastering the concept of science through scientific and practical activities.

Yusuf in his research revealed: (1) $80.7 \%$ of science learning emphasizes macroscopic and symbolic aspects carried out through lectures and exercises assisted by LKS; (2) 59.2\% management of learning and delivery of science material by teachers is delivered verbally (3) $85.2 \%$ of science teachers show a monotonous and conservative teaching pattern, namely by directly adopting the order of the subject matter in the book used and (4) $23.1 \%$ of practicum implementation by science teachers focuses more on activities that are verification, not an investigation. In other words, students are crammed with various theories and memorization of science concepts but have poor learning experiences. This makes children memorize various theories, but they do not master the concept of science, especially in the axiological aspect of solving problems (Yusuf, 2016).

Students experience weak mastery of science concepts, especially in simple aircraft material. How do we know that to facilitate our daily work, we need a tool called a simple aeroplane. There are 4 types of simple aircraft: levers (levers), inclined planes, wheels, and pulleys. The purpose of using a simple aeroplane is to 1) multiply our force or ability, 2) change the direction of the force we are acting on, and 3) travel a greater distance or increase our speed (Iman, Khaldun, \& Nasrullah, 2017: 52).

Based on preliminary studies, it was found that the phenomenon of children understanding simple planes as objects that can fly with a more exact 
shape (not like an aeroplane). Thus, teaching media are needed to help students provide real experiences through seeing, feeling, and feeling the teaching aids used. For this reason, the use of concrete media in the form of simple aircraft is expected to be able to present a more concrete learning experience that will be more appropriate for elementary school-age children. This can help the child get the correct concept of what he is learning.

Concrete objects or better known as real objects or real objects, are objects that are used to realize what is in mind with the real object. Real objects are used to explain abstract words or give real-life meaning because students gain direct experience. With concrete media, it allows teachers to be able to provide real illustrations to students. This illustration is illustrated through examples that can be obtained every day. With these examples, students are expected to play an active role in learning and discover the role of science and technology in people's lives. Even by starting learning with issues (themes) that are common around students, it is hoped that students can continue to develop the mastery of the concepts they have acquired (Hosnan, 2014: 115).

The existence of concrete media in simple planes needs to be applied through the right strategy or learning approach. Science learning that encourages to emphasize providing direct learning experiences through the use and development of mastery of scientific concepts and attitudes when they are facilitated to construct their knowledge is known as science learning, which uses a scientific inquiry approach/scientific inquiry (Na'im, Sopyan, \& Linuwih, 2015: 108).

The inquiry is learning that focuses on activities and providing direct learning experiences for students. That way, students can increase student 
understanding, and students can apply knowledge to improve their mastery of concepts. Inquiry learning will have a learning impact on students' positive mental development because through this learning, students can find and find for themselves what they need, especially in abstract learning (Suryanti, Arifin, \& Baginda, 2018: 4).

Problems in learning science in elementary schools are, of course, important to find solutions. For this reason, it is also important to carry out objective research to know the increase in concept mastery in science learning in inquiry assisted by concrete media, especially in the concept of simple aircraft that includes lever material, inclined plane, pulley, and axle wheel. Mastery of the concepts studied in this study is limited to 4 aspects, namely the domain of concept mastery used in this study is only four categories of concept mastery, namely C1 (Knowledge / Knowledge), C2 (Comprehension), C3 (Application), and C4. (Analysis / Analysis) (Suryani, Renda, \& Wibawa, 2019: 39).

\section{METHODS}

This research is a quantitative study with a quasi-experimental method. The design used is the Non-equivalent Control Group Design (Sugiyono, 2016: 118), which is described as follows:

\begin{tabular}{cccc} 
Experiment & $\mathrm{O} 1$ & $\mathrm{X} 1$ & $\mathrm{O} 2$ \\
\cline { 2 - 4 } Control & $\mathrm{P} 1$ & $\mathrm{X} 2$ & $\mathrm{P} 2$
\end{tabular}

Information:

$$
\begin{aligned}
& \mathrm{O} 1=\text { Pretest of mastery of concepts (experimental class) } \\
& \mathrm{O} 2 \text { = Posttest mastery of concepts (experimental class) }
\end{aligned}
$$


$\mathrm{X} 1=$ Treatment in the experimental class (Science learning by inquiry assisted by concrete media)

$\mathrm{X} 2=$ Treatments in dick class (Science learning assisted by audio-visual media)

P1 = Pretest of mastery of concepts (Control class)

$\mathrm{P} 2=$ Posttest mastery of concepts (Control class)

This design compares the pretest-posttest value of the experimental class given Treatment using concrete media in science learning by inquiry and the pretest-posttest control class that is given Treatment using audio-visual media in conventional science learning.

The population chosen was all students in class V-A and class V-B SDN 1 Nagrikidul Purwakarta, with as many as 60 students. The sample selection was selected by a population sample, namely by selecting 30 class A students as the experimental class and 30 class B students as the control class.

The research was carried out in three stages, namely: (1) the preparation stage, (2) the implementation stage, and (3) the final stage. At the preparation stage, the researcher made problem identification, literature study, curriculum review, determination of research subjects, preparation of instruments, and testing of research instruments. At the implementation stage, it was carried out giving a pretest, implementing learning, giving a posttest, processing the pretest and posttest data, and analyzing the results of the achievement of mastery of the science concept. The final stage is the stage of giving input in the form of conclusions and suggestions.

The learning tools used were lesson plans, worksheets, and simple plane concrete media. The instruments or data collection tools in this study were learning observation sheets and tests. The observation sheet is used to 
measure the science learning stages' feasibility through assisted inquiry concrete media. The test used is in the form of multiple-choice (objective tests) several 34 questions including levers, inclined planes, pulleys, and axle wheels with mastery of concepts covering 4 indicators, namely C1 (Knowledge), C2 (Comprehension), C3 (Application / Application), and C4 (Analysis).

The concept mastery test results were then analyzed using a software application Statistical Product and Service Solution (SPSS) 25.0 for Windows. Data analysis was carried out in descriptive analysis, assumption test (normality test and homogeneity test), paired sample test, and performing gain normalization test (N-gain). As for calculating the average $\mathrm{N}$-gain using the following gain formula:

$$
\langle\mathrm{g}\rangle=\frac{(\text { S post }- \text { S Pre })}{(\text { S mid-S Pre })}
$$

information :

$\mathrm{g}=$ average normalized gain score

Spost $=$ posttest score

Spre $=$ pretest score

Smid $=$ maximum ideal score

The results of the gain value are then consulted in the table for interpretation.

Table 1. N-gain criteria

\begin{tabular}{cc}
\hline N-gain interval & Category \\
\hline $\mathrm{g}<0.3$ & Low \\
\hline $0.3 \leq \mathrm{g} \leq 0.7$ & Moderate \\
$\mathrm{g}>0.7$ & High \\
\hline
\end{tabular}


Furthermore, to make it easier to interpreting learning outcomes in the form of mastery of the science concept, the norm of categorization of the value of mastery of the science concept is applied, which refers to the categorization of learning outcomes as follows (Syah, 2015):

Table 2. Criteria for assessment of mastery of science concepts

\begin{tabular}{ccc}
\hline No. & Score & Criteria \\
\hline 1. & $0-49.99$ & Very less \\
\hline 2. & $50-59.99$ & Not good \\
\hline 3. & $60-69.00$ & Pretty good \\
\hline 4. & $70-79.99$ & Well \\
\hline 5. & $80-100$ & Very good \\
\hline
\end{tabular}

\section{DISCUSSION}

\section{Implementation of Inquiry Science Learning}

The teacher's activity in inquiry learning science consists of seven stages of learning, namely: (1) orientation, (2) formulating problems, (3) formulating hypotheses, (4) collecting data, (5) testing hypotheses, (6) formulating conclusions, and (7) final activities. Based on the observations during the learning process, the teacher has $100 \%$ (optimally) carried out science learning in inquiry assisted by concrete media following the steps that have been determined.

\section{Student activities}

At the beginning of learning, students are guided to sit in groups and are prepared to carry out learning activities properly. Learning takes place in four learning activities. And based on the results of observations with the observer, during the four learning activities, not all students were 100\% actively involved 
in research activities. Although, in general, most students can be actively involved in research activities according to the LKS (worksheet) that has been provided, students are still found not focused and busy playing with other fellow students. This may be because not all students can be involved in researching their groups. Students who do not get a role, either holding tools or holding worksheets and writing, become unfocused,

Another obstacle that appears is that the teacher sometimes takes too long to handle problems in a group experiencing difficulties. As a result, other groups who also need guidance feel neglected and bored of waiting. This also causes more and more students to do other activities. The next obstacle is the limited time for teachers and students to do science learning by inquiry.

This incident resulted in a lack of mastery of the material by students who were not actively involved in research activities. Some of these students' scores were not satisfactory, and the increase in concept mastery was less than optimal. This needs to be a separate note and must be considered by teachers who will carry out learning activities through research.

\section{Simple Aircraft}

Every tool that is useful for facilitating human work is called an aeroplane. The plane is divided into two, namely a complicated plane and a simple plane. The goals of using simple aircraft are to a) doubling our style or abilities; b) change the direction of the forces we act on; d) going longer distances or increasing speed; d) simple planes are needed not for creating styles or saving styles. Thus, a simple plane is used to facilitate work execution, even though it requires a longer time (a longer route). There are 4 types of simple aircraft: levers (levers), 
inclined planes, wheels, and pulleys (Kejora, 2020). The types and characteristics of simple aircraft are as follows:

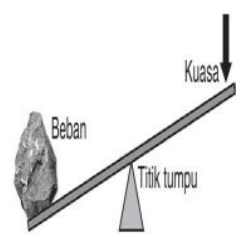

Lever

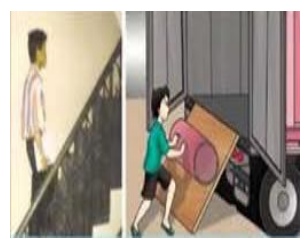

Inclined plane

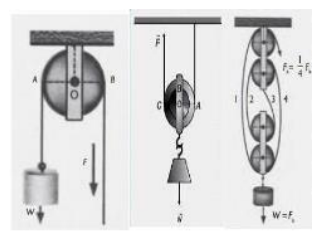

Pulley

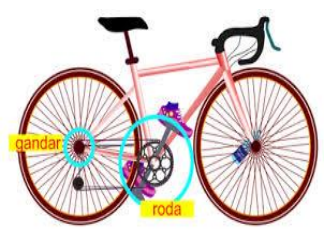

Axis Wheels

Picture 1. Simple Craft

\section{Concept Mastery}

A total of 34 questions for mastery of science concepts were given to students in the experimental class and control class, in the form of Pretest and posttest questions. The material being tested on simple planes includes levers, inclined planes, pulleys, and axle wheels. The aspects of concept mastery measured include 4 (four) cognitive levels (C1, C2, C3, and C4).

To determine the increase in the mastery of concepts that have been achieved by students and their qualifications, a normalized gain score ( $\mathrm{N}$-gain) is used. Improved conceptualization described in this section consists of general improvements and improvements for every aspect of concept mastery. The increase in concept mastery was determined through processing data on the initial test mean, final test, and $\mathrm{N}$-gain in both samples. The following are the results of concept mastery in the experimental class and control class.

The results of the students' final test average in the experimental class showed a higher increase than the control class. The N-Gain index of concept mastery in the experimental class (0.44) was included in the medium category. The N-Gain index for the control class $(0.23)$ was in a low category. 
Mudarrisa: Jurnal Kajian Pendidikan Islam, Vol. 12, No. 2, 2020

Table 3. Achievements of Science Concept Mastery

\begin{tabular}{|c|c|c|c|c|c|c|c|c|c|}
\hline \multirow[t]{2}{*}{ No. } & \multirow{2}{*}{$\begin{array}{l}\text { MASTER OF } \\
\text { CONCEPT }\end{array}$} & \multicolumn{4}{|c|}{ Experiment } & \multicolumn{4}{|c|}{ Control } \\
\hline & & Pre & post & Gain & Category & pre & post & Gain & Category \\
\hline 1 & C1 (Knowledge) & 50.00 & 65.03 & 0.28 & Low & 45.42 & 61.76 & 0.30 & Moderate \\
\hline 2 & $\begin{array}{c}\mathrm{C} 2 \\
\text { (Comprehension) }\end{array}$ & 54.41 & 70.88 & 0.31 & Moderate & 50.88 & 57.06 & 0.12 & Moderate \\
\hline 3 & C3 (Application) & 52.94 & 70.92 & 0.35 & moderate & 54.90 & 55.56 & -0.01 & Low \\
\hline 4 & C4 (Analysis) & 55.39 & 67.16 & 0.24 & Low & 55.88 & 67.65 & 0.23 & Low \\
\hline & GAIN & & 0.44 & & Moderate & & 0.23 & & Low \\
\hline
\end{tabular}

The analysis requirements test then carried out the science mastery data in two classes and the $\mathrm{N}$-gain data in the form of a normality test and a homogeneity test. The results are shown as follows:

Table 4. Normality Test \& Homogeneity Test

\begin{tabular}{|c|c|c|c|c|c|c|}
\hline \multirow[t]{2}{*}{ Class } & \multirow[t]{2}{*}{ Score } & \multirow[t]{2}{*}{ Average } & \multicolumn{2}{|c|}{ Normality test } & \multicolumn{2}{|c|}{ Homogeneity Test } \\
\hline & & & Sig & Result & Sig & Result \\
\hline \multirow[t]{2}{*}{ Experiment } & Pre & 62.16 & 0.69 & Normal & \multirow{2}{*}{0.136} & \multirow{2}{*}{ Homogeneous } \\
\hline & Post & 79.61 & 0.48 & Normal & & \\
\hline \multirow[t]{2}{*}{ Control } & Pre & 60.39 & 0.62 & Normal & \multirow{2}{*}{0.365} & \multirow{2}{*}{ Homogeneous } \\
\hline & Post & 67.06 & 0.66 & Normal & & \\
\hline \multicolumn{2}{|c|}{ Experimental Gain } & 0.44 & 0.81 & Normal & \multirow[t]{2}{*}{0.726} & \multirow[t]{2}{*}{ Homogeneous } \\
\hline Gain Contro & & 0.23 & 0.64 & Normal & & \\
\hline
\end{tabular}

Based on the data, it can be seen clearly that the data of the two classes and the gain data for the aspect of normalized concept mastery are homogeneous; this can be seen from the significance $\geq 0.05$. The data analysis was continued to test the hypothesis regarding the difference in concept mastery improvement in the experimental class and the control class. The 
hypothesis was formulated in the form of a statistical hypothesis of the average difference test as follows:

$$
\begin{aligned}
& \text { HO: } \mu 1=\mu 2 \\
& \text { Ha: } \mu 1 \neq \mu 2
\end{aligned}
$$

with

H02: There is no significant difference between the increase in concept mastery of students who receive inquiry learning by utilizing concrete media and the conceptual mastery of students who receive conventional learning assisted by audio-visual media.

$\mathrm{Ha2}$ : There is a significant difference between the increase in conceptual mastery of students who receive inquiry learning by utilizing concrete media and the conceptual mastery of students who receive conventional learning assisted by audio-visual media.

Table 5. Hypothesis Test Results of Concept Mastery

\begin{tabular}{cccccc}
\hline Class & Score & Average & t-Count & Table & Sig \\
\cline { 1 - 2 } Experiment & N-gain & 0.46 & \multirow{2}{*}{2,688} & 2,045 & 0.012 \\
\cline { 1 - 1 } Control & & 0.17 & & & \\
\hline
\end{tabular}

Based on the calculation, the $t_{\text {count }}$ is 3.368 at the significance level or $\alpha$ of 0.05 , the degrees of freedom $\mathrm{df}(29)$ so that $\mathrm{t}_{\text {table }}(29)=2.045$. By looking at the results of $t_{\text {count }}$ and $t_{\text {table }}$, it can be seen that $t_{\text {count }}=3.368>t$ table $=2.045$, with a sig. $0.002<\alpha$ amounting to 0.05 , then $\mathrm{H}_{0}$ is rejected, and $\mathrm{Ha}$ is accepted. This shows a difference in the average increase in concept mastery of students who receive inquiry learning by utilizing concrete media with the mastery of concepts from students who receive conventional learning assisted by audiovisual media. 
The data analysis results showed that the experimental class N-Gain (0.44) was more significant than the control class N-Gain (0.23). Thus, it can be concluded that learning using concrete media in inquiry learning science improves concept mastery more than conventional learning assisted by audiovisual media.

The difference in student final test results is influenced because in inquiry learning science, students are motivated to seek their own knowledge through learning experiences by utilizing concrete media. This is in line with what was expressed by Hosnan that real objects are used to explain abstract words or give real-life meaning because students experience direct experience (Hosnan, 2014). The presence of concrete media in stimulating student questions on strengthening activities in learning has quite a lot to do with learning outcomes because by bringing up concrete media that is following the concept of the material so that the material to be studied becomes concrete for students because students in their daily lives can encounter it.

Hosnan (2014) states that inquiry learning brings students to a problem that contains a puzzle. The problem presented is a problem that challenges students to think about solving the puzzle. It is said to be a riddle because there is certainly an answer to the problem or puzzle, and students are encouraged to find the right answer. The process of seeking answers is very important in inquiry activities. Therefore, through this process, students will gain valuable experience to develop through the thought process.

Inquiry activity begins by presenting students with an enigmatic event. These events are, of course, natural events that students can experience every day. This concrete media will generate curiosity in students to then seek their knowledge through experimental activities. The learning process will run well 
and creatively if the teacher provides opportunities for students to find a concept, theory, rule, or understanding through examples that they encounter in their life.

The inquiry training learning model can create conditions so that students ask why an event occurs, carry out activities, seek answers, process data logically, and carry out intellectual development strategies that can be used to find why a phenomenon can occur. Active student involvement in learning is very important in cognitive learning theory because only by activating students will the process of assimilation and accommodation of knowledge and experience occur well. The increase in students' abilities after inquiry learning is because, in the presentation of each material during the learning process, it focuses more on student activity in learning so that it is faster to assimilate science concepts and principles (Suryanti et al., 2018).

Learning to understand will be more meaningful than learning to memorize. To be meaningful, new information must be adapted and linked to the knowledge students already have. By being actively involved in learning activities, it is clear that students' understanding and mastery of science concepts is better than classes that only do conventional science learning assisted by audio-visual media (Munadi, 2013).

Increased mastery of science concepts in classes that carry out inquiry learning science by utilizing concrete media is in line with the results of research conducted by Yusran, which states that inquiry learning can increase students' intellectual potential because they are allowed to look for and find regularities. Things that are interconnected through their observations and experiences to prolong the student's memory process for a long time. The process that students experience makes the information that enters the 
student's memory bank more durable and easier to recall when needed (Tarmidzi, 2013).

In the experimental class that carries out inquiry learning science by utilizing concrete media, learning activities focus more on student activeness. Students are faced directly with investigative situations that make it easier for students to relate the newly acquired knowledge to the knowledge that is already in their minds.

The increase in student ability is caused through inquiry learning. Students carry out separate experiments so that students are directly exposed to an atmosphere of investigation, which can help them identify a problem conceptually so that students more quickly assimilate the concepts and principles in science lessons. Whereas in a class that implements science learning conventionally, the teacher considers that teaching is only limited to delivering subject matter, so the results will, of course, be different from classes that involve active students in learning activities because the teacher in this class thinks that teaching is a process of assisting students (Sani, 2014).

\section{CONCLUSION}

Inquiry-based science learning using simple plane concrete media can improve the conceptual mastery of elementary school students. However, it is necessary to make various improvements and further improvements. Learning can achieve optimal improvement, and there needs to be a directed and systematic learning plan. The inquiry learning stage should be integrated with concrete media and the conceptual mastery stage. In learning, conditioning needs to be done effectively and efficiently, considering the limited learning time. It needs to be supported by worksheets and clear practicum procedures in guiding 
students. Also required is a question instrument relevant to the aspects of conceptual mastery that will be strengthened. It is also important to design learning media that can be used in conventional learning to improve concept mastery.

\section{REFERENCES}

Ardianto, D., \& Rubini, B. (2016). Comparison Of Students Scientific Literacy In Integrated Science Learning Through Model Of Guided Discovery And Problem Based Learning. Jurnal Pendidikan IPA Indonesia, 5(1), 31-37.

Duruk, U., Akgün, A., Doğan, C., \& Gülsuyu. (2018). Examining the

Learning Outcomes Included in the Turkish Science Curriculum in Terms of Science Process Skills: A Document Analysis with StandardsBased Assessment. International Journal of Environmental $\mathcal{E}$ Science Education, 12(2), 117-142.

Handika, I., \& Wangid, M. N. (2013). Pengaruh Pembelajaran Berbasis

Masalah Ilham Handika, Muhammad Nur Wangid 85. Jurnal Prima Edukasia, I(1), 85-93.

Hosnan, M. (2014). Pendekatan Saintifik Dan Kontekstual Dalam Pembelajaran Abad 21. Bogor: Ghalia Indonesia.

Iman, R., Khaldun, I., \& Nasrullah. (2017). Meningkatkan Kemampuan Berpikir Kritis Siswa Dengan Model Inkuiri Terbimbing Pada Materi Pesawat Sederhana. Jurnal Pendidikan Sains Indonesia, 5(1), 52-58.

Kejora, M. T. B. (2020). The Use of Concrete Media in Science Learning in Inquiry to Improve Science Process Skills for Simple Machine subject. 
MUDARRISA: Jurnal Kajian Pendidikan Islam, 12(1), 1-17.

Muakhirin, B. (2014). Peningkatan Hasil Belajar Ipa Melalui Pendekatan

Pembelajaran Inkuiri Pada Siswa Sd. Jurnal Ilmiah Guru Caraka Olah Pikir Edukatif "COPE," 1(1), 51-57.

Munadi, Y. (2013). Media Pembelajaran Sebuah Pendekaatan Baru. Jakarta: Referensi (Gp Press Production).

Na'im, M. ., Sopyan, A., \& Linuwih, S. (2015). Implementasi Model Discovery-Inquiryberbasis Pendekatan Scientificpada Pembelajaran IPA Di Kelas V Sekolah Dasar. 4 (2), 104-111.

Rosarina, G., Sudin, A., \& Sujana, A. (2016). Penerapan Model Discovery Learning Untuk Meningkatkan Hasil Belajar Siswa Pada Materi Perubahan Wujud Benda. Jurnal Pena Ilmiah, 1(1), 371-380.

Samatowa, U. (2010). Pembelajaran IPA Di Sekolah Dasar. Jakarta: PT. Indeks. Sani, R. . (2014). Pembelajaran Saintifik Untuk Implementasi Kurikulum 2013. Bandung: Bumi Aksara.

Setiawan, D. W., Suhartono, \& Triyanto. (2019). The Influence of Active Learning on the Concept of Mastery of Sains Learning by Fifth Grade Students at Primary School. International Journal of Educational Methodology, 5(1), 177-181.

Shahali, E. H. M., Halim, L., \& Treagust, D. F. (2015). Primary School Teachers' Understanding of Science Process Skills in Relation to Their Teaching Qualifications and Teaching Experience. Research Science in Education, 47(1), 257-281.

Suduc, A., Bizoi, M., \& Gorghiu, G. (2015). Inquiry-Based Science Learning in Primary Education. Procedia - Social and Behavioral Sciences, 20(5), 474-479. 
Sugiyono. (2016). Metode Penelitian Kombinasi (Mix Methode). Bandung: Alfabeta.

Suryani, N. K., Renda, N. T., \& Wibawa, I. M. C. (2019). Pengaruh Pendekatan Saintifik Berorientasi Konsep IPA dan Keterampilan Proses Sains Siswa Kelas V SD Di Gugus VII Kecamatan Sukasada Kabupaten Buleleng. Journal of Education Technology., 3(1), 35-43.

Suryanti, Arifin, I., \& U, B. (2018). The Application of Inquiry Learning to Train Critical Thinking Skills on Light Material of Primary School Students. Journal of Physics: Conference Series PAPER, 1-7. https://doi.org/doi :10.1088/1742-6596/1108/1/012128

Syah, M. (2015). Psikologi Pendidikan Pendekatan Baru. Bandung: Alfabeta.

Tarmidzi. (2013). Pemanfaatan Fenomena Dalam Pembelajaran IPA Secara Inkuiri Untuk Meningkatkan Penguasaan Konsep Dan Keterampilan Proses Sains Siswa Sekolah Dasar. Bandung: Universitas Pendidikan Indonesia.

Yusuf, M. (2016). Pengaruh Penerapan Pembelaajaran Pengalaman Menggunakan Percobaaan Secara Inkuiri Terhadap Peningkatan Kemampuan Memahami Dan Penguasaan konsep Pada Siswa Sekolah Dasar. Bandung: Universitas Pendidikan Indonesia. 